\title{
Seed priming with iron and zinc improves growth and yield of groundnut (Arachis hypogaea L.)
}

\section{Tahir Amir Khan ${ }^{1 *}$, Zammurad Iqbal Ahmed ${ }^{2}$, Sairah Syed ${ }^{3}$, Abdullah Baloch $^{1}$, Muhammad Naveed Malik ${ }^{2}$, Muhammad Irfan², Waqas Ahmad $^{4}$, Abdul Latif ${ }^{1}$, Zulfiqar Ali Rahujo ${ }^{5}$ and Sumeria Muhammad Hussain ${ }^{4}$}

1. Balochistan Agricultural Research \& Development Centre, Quetta-Pakistan

2. Department of Agronomy, PMAS-Arid Agriculture University Rawalpindi-Pakistan

3. Directorate of Agronomic Research, Ayub Agriculture Research Institute Faisalabad-Pakistan

4. National Agricultural Research Centre, Islamabad-Pakistan

5. Agricultural Research Institute, Jaffarabad-Pakistan

*Corresponding author's email: info.maliktahir@gmail.com

Citation

Tahir Amir Khan, Zammurad Iqbal Ahmed, Sairah Syed, Abdullah Baloch, Muhammad Naveed Malik, Muhammad Irfan, Waqas Ahmad, Abdul Latif, Zulfiqar Ali Rahujo and Sumeria Muhammad Hussain. Seed priming with iron and zinc improves growth and yield of groundnut (Arachis hypogaea L.). Pure and Applied Biology. Vol. 6, Issue 2, pp553-560. http://dx.doi.org/10.19045/bspab.2017.60057

Received: 13/01/2017 Revised: 08/04/2017

Accepted: 13/04/2017

Online First: 18/04/2017

\section{Abstract}

Seed priming is considered as an important component that results in early establishment of crop seedling. Thus, the effect of seed priming with iron $(\mathrm{Fe})$ and zinc $(\mathrm{Zn})$ on growth and yield components of groundnut ( $c v$. BARI-2011) was evaluated by using different doses of Fe $(0.1 \%$ and $0.3 \%)$ and $\mathrm{Zn}(0.5 \%$ and $1.0 \%)$ in RCBD design with two factors factorial arrangement having three replications. The crop was grown in April, 2016 at the Research Farm of PMASArid Agriculture University, Rawalpindi, (Pothowar Pleatue) Punjab, Pakistan. Data revealed that plant height and number of plants were highest at $0.3 \% \mathrm{Fe}$ in combination with $1.0 \% \mathrm{Zn}$. Similarly, numerical values for all measured yield components i.e., number of pods plant ${ }^{-1}$, kernel weight $\left(\mathrm{kg} \mathrm{ha}^{-1}\right), 100$ kernel weight $(\mathrm{g})$, pod yield $\left(\mathrm{kg} \mathrm{ha}^{-1}\right)$, biological yield $\left(\mathrm{kg} \mathrm{ha}^{-1}\right)$, harvest index (HI) and shelling percentage were significantly higher at $0.3 \% \mathrm{Fe}$ in combination with $1.0 \% \mathrm{Zn}$ as compared to the control. The control plot resulted in the lowest values for all the parameters studied. It can be inferred from the results that seed priming at the rate of $0.3 \% \mathrm{Fe}$ in combination with $1 \% \mathrm{Zn}$ is recommended for obtaining higher yield of groundnut.

Keywords: Micronutrients; Seed priming; BARI-2011; Kernel; Pothowar tract

\section{Introduction}

Groundnut (Arachis hypogaea L.) is the fourth-largest oilseed crop in the world, cultivated in more than 100 countries [1]. Worldwide, it is cultivated on 25.41 million hectares whereas the share of Pakistan is 0.0938 million hectares [2]. Groundnut is used for direct consumption, in confectionary industry and as a vegetable oil for cooking. Moreover, groundnut restores 
nitrogen into the soil by fixing it without upsetting non-renewable resources or disturbing balance in the environment and thus is considered as one of the most important legume crop [3]. In Pakistan, groundnut is grown mainly in rainfed areas. In 2011-12, out of total peanut cultivated area, about $91 \%$ lies in Punjab, $8 \%$ in Khyber Pakhtun khwa (KPK), and $1 \%$ in Sindh [4]. About $85 \%$ of total area under groundnut cultivation in Punjab lies in the Pothowar tract, producing $71 \%$ of the country's total production [5]. Among other factors, micronutrient deficiency is an important factor for low crop productivity of groundnut in these areas. Zinc plays a vital role in the germination and crop growth [6, 7] but overall Pakistani soils are deficient in micronutrients, especially in Zinc, Iron and Copper [8].

Due to the calcareous nature of soils, in many arid areas, alkaline $\mathrm{pH}$, poor organic matter status, salinity, drought stress and improper utilization of fertilizer, deficiency of micronutrients is a common problem in plants, $[9,10]$ therefore, the combined use of macro and micro nutrients is very important for increasing the crop production [11]. Micronutrients are vital for various physiological processes such as photosynthesis, respiration, cell elongation, cell maturation, development of meristematic tissue and formation of protein [12]. Among micronutrients, $\mathrm{Zn}$ deficiency affects the productivity of groundnut, [13] negatively influencing the quality and yield components of grain. Beside $\mathrm{Zn}, \mathrm{Fe}$ is essential for all living beings and indispensable for various activities [14]. It is a vital part of many proteins and plant pigments [15]. Though iron is sufficiently present in most soils, but not in the forms available to plants i.e. ferric form [16].

In crop plants, seed invigoration is a broader term and has been used in two different ways, i.e., seed priming and foliar application [17]. Seed priming improves the germination speed [18], minimizes the time between sowing and emergence, enhances seedling emergence and vigor, crop establishment and uplift yield [19-21]. Nutri-priming technique is considered to be an efficient way from economic point of view as it uses low doses of micronutrients and is easy to operate. It also facilitates the vigorous germination and seedling emergence, better stand establishment and crop growth [22].

In the light of the importance of micronutrients, the main objective of the present study was to evaluate the effects of seed priming with micronutrients i.e. iron and zinc on the growth, yield and yield components of groundnut.

\section{Materials and methods}

The study was carried out to determine the effects of seed priming with $\mathrm{Fe}$ and $\mathrm{Zn}$ on the growth and yield of groundnut from April to October, 2016 at University Research Farm $\left(33.11^{\circ} \mathrm{N}\right.$ latitude to $73.01^{\circ}$ E longitude), Chakwaal Road, PMAS- Arid Agriculture University, Rawalpindi (Pothwar pleatue), Punjab, Pakistan. The climate of the region is semi-arid with annual rainfall of $850 \mathrm{~mm}$ and soil of the farm varies from sandy loam to loam in texture with $\mathrm{pH}$ ranging from 7.7 to 7.8. An approved variety of groundnut ( $c v$. BARI2011) was used. The seeds of groundnut were obtained from National Agricultural Research Center, Islamabad, Pakistan. The seeds were sown using hand drill in rows at a depth of 2-3 cm from the soil surface. Row-row and plant-plant distance was maintained at 45 and $10 \mathrm{~cm}$, respectively. The experiment was laid out in a Randomized Complete Block Design (RCBD) with two factors factorial arrangement (Fe and $\mathrm{Zn}$ ) and replicated three times. The field was divided into 3 blocks, each containing 9 plots of size 3.15 $\mathrm{m} \times 3 \mathrm{~m}$ with a total plot size of $330 \mathrm{~m}^{2}$. 
Three levels of iron, viz. [0 (control), $0.1 \%$ and $0.3 \%$ solution] and three levels of zinc, viz. [0 (control), $0.5 \%$ and $1 \%$ solution] were used to treat the groundnut seeds before sowing. Solutions of the required concentrations of $\mathrm{Fe}$ and $\mathrm{Zn}$ were prepared in 9 beakers and the seeds were soaked in these solutions for 8 hours. Treatment combinations were randomly allocated in each block. Basal dose of fertilizer was applied at the rate of 30-80-30 NPK kg ha-1. The crop was sown only on rain water. No irrigation was given throughout the growing season of the crop.

The studied growth parameters were: number of plants $\left(\mathrm{m}^{-2}\right)$ at maturity, plant height $(\mathrm{cm})$ and yield and yield contributing parameters were: number of pods plant $^{-1}$, kernel weight $\left(\mathrm{kg} \mathrm{ha}{ }^{-1}\right)$, hundred kernel weight $(\mathrm{g})$, pod yield $\left(\mathrm{kg} \mathrm{ha}^{-1}\right)$, biological yield $\left(\mathrm{kg} \mathrm{ha}^{-1}\right)$, harvest index (HI) and shelling percentage (SP).

Harvest index for each plot was calculated by using the following formula:

Harvest Index $(\mathrm{HI})=($ Grain Yield $/$ Biological Yield $) \times 100$

Shelling percentage for each plot was calculated by dividing the kernel weight $(\mathrm{kg}$ $\left.\mathrm{ha}^{-1}\right)$ with pod weight $\left(\mathrm{kg} \mathrm{ha}{ }^{-1}\right)$ and then multiplied by 100. The formula used to calculate shelling percentage was as follows Shelling Percentage $(\mathrm{SP})=($ Kernel Weight $/$ Pod Weight $) \times 100$ Collected data was subjected to analysis of variance (ANOVA) by Statistics 8.1 and the differences among treatment means were compared by Tukey's honest significant difference test (HSD).

\section{Soil sampling}

Soil sampling was done with the help of agar for soil fertility determination before sowing and after harvesting. The samples were collected from 5 randomly selected points from the field at the depth of $15 \mathrm{~cm}$ and composite sample was prepared. The analysis was carried out at the Laboratory, Department of Soil Fertility Analysis and Water Status, Rawalpindi, Pakistan for the determination of soil iron and zinc status.
The soil analysis showed that the soil was low in both micronutrients. The levels of iron and zinc in the soil before sowing were 0.83 and $0.56 \mathrm{ppm}$, respectively. After harvesting, it was observed that the levels of iron and zinc were considerably low i.e., 0.27 and $0.35 \mathrm{ppm}$, respectively.

\section{Results}

\section{Growth parameters}

The number of plants and plant height calculated at maturity was significantly affected by the levels of iron while in case of zinc, the effect was significant for number of plants and non-significant for plant height (Figure 1 and 2). It was noticed that the number of plants increased with increase in iron and zinc concentrations. Maximum number of plants $\left(\mathrm{m}^{-2}\right)$ of groundnut was recorded at the highest tested concentrations for both the micronutrients $(0.3 \% \mathrm{Fe}$ and $1 \%$ $\mathrm{Zn}$ ) and the lowest number of plants was found in the control. The data presented in Figure 1 depicted that the plant height responded positively to iron application. The plant height of groundnut was increased with the increase in iron concentrations where taller plants $(41.50 \mathrm{~cm})$ of groundnut were recorded at $0.3 \% \mathrm{Fe}$ and shorter plant height were found in the control i.e., 35.46 $\mathrm{cm}$.

The interaction $(\mathrm{Fe} \times \mathrm{Zn})$ was significant for number of plants and plant height of groundnut (Table 1). The interaction $0.3 \%$ Fe $\times 1 \% \mathrm{Zn}$ produced 20 plants $\mathrm{m}^{-2}$ of groundnut but the effect of $\mathrm{Fe}$ was more visible as compared to $\mathrm{Zn}$. Because seed priming with $0.3 \%$ Fe resulted in significantly higher number of plants (18.8 $\mathrm{m}^{-2}$ ), compared to seed priming with $1 \% \mathrm{Zn}$ where number of plants $\left(15.6 \mathrm{~m}^{-2}\right)$ was found which was non-significantly higher than the control. The interaction effect of the highest levels of micronutrients $(0.3 \% \mathrm{Fe} \times$ $1 \% \mathrm{Zn}$ ) produced the maximum plant height of groundnut, i.e., $42.3 \mathrm{~cm}$ that was statistically at par with the interactions $0.3 \%$ 
$\mathrm{Fe}, 0.3 \% \mathrm{Fe} \times 0.5 \% \mathrm{Zn}$ and $0.1 \% \mathrm{Fe} \times 1 \%$ $\mathrm{Zn}$ (Table 1). The minimum $(34.5 \mathrm{~cm})$ plant

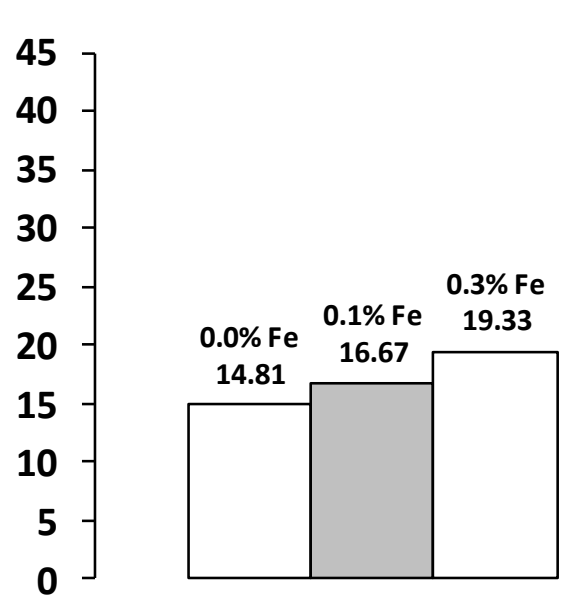

No. of Plants per sq. meter height of groundnut was recorded in the control.

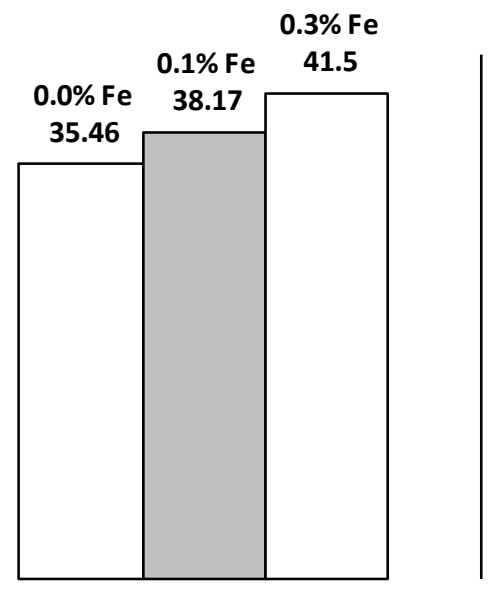

Plant Height (cm)

Figure 1. Effect of various levels of Fe on the growth parameters of groundnut

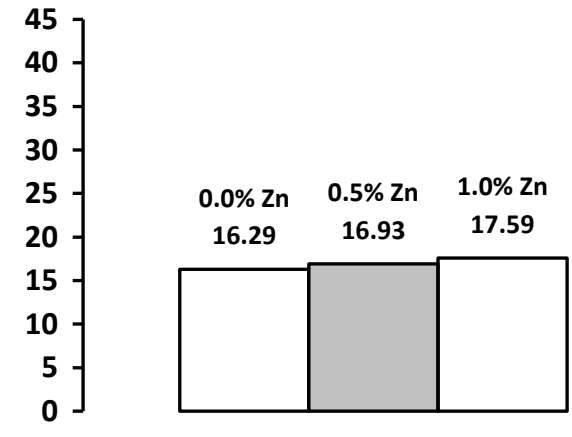

No. of Plants per sq. meter

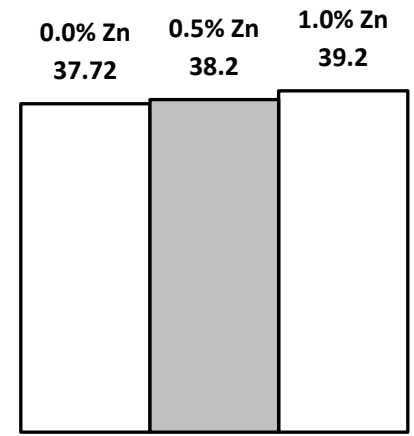

Plant Height $(\mathrm{cm})$

Figure 2. Effect of various levels of $\mathrm{Zn}$ on the growth parameters of groundnut

Table 1. Interaction effect of various levels of $\mathrm{Fe}$ and $\mathrm{Zn}$ on the growth parameters of groundnut

\begin{tabular}{|c|c|c|}
\hline Interactions & Number of plants $\left(\mathrm{m}^{-2}\right)$ & Plant height $(\mathrm{cm})$ \\
\hline Control & $14 \mathrm{f}$ & $34.5 \mathrm{e}$ \\
\hline $0.1 \% \mathrm{Fe}$ & 16.1def & $37.2 \mathrm{cde}$ \\
\hline $0.3 \% \mathrm{Fe}$ & $18.8 \mathrm{abc}$ & $40.7 \mathrm{abc}$ \\
\hline $0.5 \% \mathrm{Zn}$ & $14.9 \mathrm{ef}$ & 35.9de \\
\hline $1.0 \% \mathrm{Zn}$ & 15.6def & $36.1 \mathrm{de}$ \\
\hline $0.1 \% \mathrm{Fe} \times 0.5 \% \mathrm{Zn}$ & $16.7 \mathrm{cde}$ & 38.1 bcde \\
\hline $0.1 \% \mathrm{Fe} \times 1.0 \% \mathrm{Zn}$ & $17.2 \mathrm{bcd}$ & 39.2abcd \\
\hline $0.3 \% \mathrm{Fe} \times 0.5 \% \mathrm{Zn}$ & $19.2 \mathrm{ab}$ & $41.5 \mathrm{ab}$ \\
\hline $0.3 \% \mathrm{Fe} \times 1.0 \% \mathrm{Zn}$ & $20 . \mathrm{a}$ & $42.3 \mathrm{a}$ \\
\hline $\begin{array}{ll}\text { For No. of Plants) } & \text { HSD }=5 \%, \\
\text { For Plant Height) } & \text { HSD }=5 \%,\end{array}$ & $\begin{array}{l}\mathrm{Fe}=0.97 \\
\mathrm{Fe}=1.75\end{array}$ & $\begin{array}{l}\text { Interaction }=2.31 \\
\text { Interaction }=4.17\end{array}$ \\
\hline
\end{tabular}

Means not sharing a letter in common differ significantly at $P=0.05$ 


\section{Yield components}

The number of pods plant $^{-1}$, kernel weight, 100 kernel weight, pod yield, biological yield, harvest index and shelling percentage were significantly affected by the levels of iron and zinc (Table 2). It was noticed that yield and all yield components increased by using higher doses of iron and zinc. Maximum values for number of pods (42.7), kernel weight (1715.6 kg ha-1), 100 kernel weight $(60.4 \mathrm{~g})$, pod yield $\left(2537.2 \mathrm{~kg} \mathrm{ha}^{-\mathbf{1}}\right)$, biological yield $\left(7623.9 \mathrm{~kg} \mathrm{ha}^{-1}\right)$, harvest index $(22.5 \%)$ and shelling \% (67.6) were recorded at $0.3 \% \mathrm{Fe}$ level. As compared to the treated plots, control resulted in lower values for all the variables.

The interaction effect of $\mathrm{Fe}$ and $\mathrm{Zn}$ on the yield and yield components of groundnut was also significant (Table 3). The interaction $(0.3 \% \mathrm{Fe} \times 1.0 \% \mathrm{Zn})$ produced significantly higher pod yield $(2603.8 \mathrm{~kg} \mathrm{ha}$ ${ }^{1}$ ) of groundnut followed by $0.3 \% \mathrm{Fe} \times 0.5 \%$ $\mathrm{Zn}$. The other interaction was found to be non-significant with each other.

Table 2. Effect of various levels of $\mathrm{Fe}$ and $\mathrm{Zn}$ on the yield and yield components of groundnut (main effects)

\begin{tabular}{|c|c|c|c|c|c|c|c|}
\hline Treatments & $\begin{array}{l}\text { No. of Pods } \\
\text { plant }^{-1}\end{array}$ & $\begin{array}{l}\text { Kernel } \\
\text { Weight } \\
\left(\mathrm{kg} \mathrm{ha}^{-1}\right)\end{array}$ & $\begin{array}{l}100 \text { Kernel } \\
\text { weight (g) }\end{array}$ & $\begin{array}{l}\text { Pod Yield } \\
\left(\mathrm{kg} \mathrm{ha}^{-1}\right)\end{array}$ & $\begin{array}{l}\text { Biological } \\
\text { Yield } \\
\left(\text { kg ha-1 }^{-1}\right)\end{array}$ & $\begin{array}{l}\text { Harvest } \\
\text { Index } \\
(\%)\end{array}$ & $\begin{array}{l}\text { Shelling } \\
\%\end{array}$ \\
\hline \multicolumn{8}{|l|}{$\mathbf{F e}$} \\
\hline Control & $33.2 \mathrm{~b}$ & $1286.7 \mathrm{c}$ & $42 \mathrm{c}$ & $2186.1 \mathrm{c}$ & $6702.6 c$ & $19.2 \mathrm{c}$ & $58.9 \mathrm{c}$ \\
\hline $0.1 \%$ & $40.8 \mathrm{a}$ & $1469 b$ & $49.5 \mathrm{~b}$ & $2311.2 b$ & $7089.6 b$ & $20.7 b$ & $63.5 b$ \\
\hline $0.3 \%$ & $42.7 \mathrm{a}$ & $1715.6 \mathrm{a}$ & $60.4 \mathrm{a}$ & $2537.2 \mathrm{a}$ & $7623.9 \mathrm{a}$ & $22.5 a$ & $67.6 \mathrm{a}$ \\
\hline \multicolumn{8}{|l|}{$\mathbf{Z n}$} \\
\hline Control & $36.8 \mathrm{~b}$ & $1419.1 \mathrm{c}$ & $48 \mathrm{c}$ & $2282.4 b$ & $6968 b$ & $20.3 \mathrm{c}$ & $62 c$ \\
\hline $0.5 \%$ & $38.7 b$ & $1480.7 b$ & $50 \mathrm{~b}$ & $2340.4 b$ & $7140.8 \mathrm{ab}$ & $20.7 b$ & $63 b$ \\
\hline $1.0 \%$ & $41.3 \mathrm{a}$ & $1571.5 \mathrm{a}$ & $53.9 \mathrm{a}$ & $2411.6 \mathrm{a}$ & $7307.45 \mathrm{a}$ & $21.4 \mathrm{a}$ & $64.9 \mathrm{a}$ \\
\hline
\end{tabular}

Means not sharing a letter in common differ significantly at $P=0.05$

Table 3. Interaction effect of various levels of $\mathrm{Fe}$ and $\mathrm{Zn}$ on the yield and yield components of groundnut

\begin{tabular}{|c|c|c|c|c|c|c|c|}
\hline Interactions & $\begin{array}{l}\text { No. of } \\
\text { Pods } \\
\text { plant }^{-1}\end{array}$ & $\begin{array}{l}\text { Kernel } \\
\text { Weight } \\
\left(\mathbf{k g ~ h a}^{-1}\right)\end{array}$ & $\begin{array}{l}100 \\
\text { Kernel } \\
\text { weight (g) }\end{array}$ & $\begin{array}{l}\text { Pod Yield } \\
\left(\mathrm{kg} \mathrm{ha}^{-1}\right)\end{array}$ & $\begin{array}{l}\text { Biological } \\
\text { Yield } \\
\left(\mathrm{kg} \mathrm{ha}^{-1}\right)\end{array}$ & $\begin{array}{l}\text { Harvest } \\
\text { Index } \\
(\%)\end{array}$ & $\begin{array}{l}\text { Shelling } \\
\%\end{array}$ \\
\hline Control & $30.5 \mathrm{e}$ & $1245 f$ & $40.5 \mathrm{f}$ & $2170.8 \mathrm{~d}$ & $6609.5 \mathrm{f}$ & $18.8 \mathrm{~g}$ & $57.4 \mathrm{~g}$ \\
\hline $0.1 \% \mathrm{Fe}$ & $38.9 \mathrm{bc}$ & 1386de & $46.4 \mathrm{e}$ & $2222.1 d$ & 6921.3def & $20 \mathrm{de}$ & $62.4 \mathrm{ef}$ \\
\hline $0.3 \% \mathrm{Fe}$ & $42.06 \mathrm{ab}$ & $1626.32 b c$ & $56.53 \mathrm{bc}$ & $2454.36 \mathrm{ab}$ & $7373.1 \mathrm{bc}$ & $22.1 \mathrm{bc}$ & $66.3 \mathrm{bc}$ \\
\hline $0.5 \% \mathrm{Zn}$ & $32.8 \mathrm{de}$ & 1277ef & $41.1 \mathrm{f}$ & $2187 \mathrm{~d}$ & $6693.5 \mathrm{ef}$ & $19.1 \mathrm{fg}$ & $58.4 \mathrm{~g}$ \\
\hline $1.0 \% \mathrm{Zn}$ & $36.4 \mathrm{~cd}$ & 1338.2def & $44.5 \mathrm{ef}$ & $2200.4 d$ & 6804.9ef & $19.7 \mathrm{ef}$ & $60.8 \mathrm{f}$ \\
\hline $\begin{array}{l}0.1 \% \mathrm{Fe} \times \\
0.5 \% \mathrm{Zn} \\
\end{array}$ & $41 \mathrm{abc}$ & $1444.6 d$ & 49de & $2280.9 \mathrm{~cd}$ & 7081.2cde & $20.4 d$ & 63.3de \\
\hline $\begin{array}{l}0.1 \% \mathrm{Fe} \times \\
1.0 \% \mathrm{Zn}\end{array}$ & 41.1abc & $1576.3 \mathrm{c}$ & $53.2 \mathrm{~cd}$ & $2430.5 b c$ & $7266.4 \mathrm{bcd}$ & $21.7 \mathrm{c}$ & $64.9 \mathrm{~cd}$ \\
\hline $\begin{array}{l}0.3 \% \mathrm{Fe} \times \\
0.5 \% \mathrm{Zn}\end{array}$ & $42.28 \mathrm{ab}$ & $1720.54 \mathrm{ab}$ & $60.70 \mathrm{ab}$ & $2553.38 \mathrm{ab}$ & $7647.8 \mathrm{ab}$ & $22.5 \mathrm{ab}$ & $67.4 b$ \\
\hline $\begin{array}{l}0.3 \% \mathrm{Fe} \times \\
1.0 \% \mathrm{Zn}\end{array}$ & $45.11 \mathrm{a}$ & $1800.05 \mathrm{a}$ & $64.00 \mathrm{a}$ & $2603.83 \mathrm{a}$ & $7850.7 \mathrm{a}$ & $22.9 a$ & $69.1 \mathrm{a}$ \\
\hline
\end{tabular}

Means not sharing a letter in common differ significantly at $P=0.05$ 


\section{Discussion}

Seed priming governs cellular, sub-cellular and molecular changes in seeds and enhances seed vigor during germination and emergence that resulted in good crop stand and ultimately better growth of crop [23, 24]. In the present study, seed priming with $\mathrm{Fe}$ and $\mathrm{Zn}$ improved the number of plants, plant height, yield and yield components, suggesting that the seed priming is important for increasing the overall yield of groundnut. Increase in number of pods plant ${ }^{-1}$ and kernel weight of groundnut may be attributed to $\mathrm{Fe}$ which is known to enhance the nitrogenase activity resulting in the better nodule and peg formation thereby boosting the production of number of pods plant $^{-1}$ [25]. Similarly, kernels of treated plots with $\mathrm{Fe}$ and $\mathrm{Zn}$ were healthy with vigorous growth and larger in size which resulted in the increase of 100 kernel weight. Whereas, kernels of control plots were smaller due to the stunted growth of plants. These results are in line with Mirshekari et $a l$. [26] who reported the positive effects of seed priming with iron and boron on 1000 seed weight of groundnut.

In our study, the highest pod and biological yield of groundnut was noted in $\mathrm{Fe}$ and $\mathrm{Zn}$ treated plots. This may be attributed to the increased number of pods plant ${ }^{-1}$ of groundnut due to the seed priming with $\mathrm{Fe}$ and $\mathrm{Zn}$. The improvement in the biological yield of groundnut with $\mathrm{Fe}$ and $\mathrm{Zn}$ may be attributed to seed priming with zinc which is responsible for the better crop emergence, seedling vigor, yield and biomass of the crop [27].

Seed priming with $\mathrm{Fe}$ and $\mathrm{Zn}$ also showed the better harvest index and shelling percentage as compared to the control. The highest shelling percentage of harvest index with $\mathrm{Fe}$ and $\mathrm{Zn}$ seed priming might be due to more economic yield, i.e., healthy kernels with no empty pod. Ali and Seyyed [25] presented results which are very close to our findings that $\mathrm{Fe}$ application through seed treatment resulted in the better shelling percentage and harvest index of groundnut crop.

\section{Conclusion}

Findings of this study suggests that seed priming with combination of $\mathrm{Fe}$ and $\mathrm{Zn}$ $(0.3 \%$ and $1 \%)$ resulted in the better growth and yield of groundnut (variety BARI2011). These research findings have an implication for enhancement of yield of groundnut which can be further implied on other leguminous crops. Moreover, further investigation on higher levels above $0.3 \%$ and $1 \%$ of $\mathrm{Fe}$ and $\mathrm{Zn}$, respectively can be a step forward to identify the highest beneficial levels of $\mathrm{Fe}$ and $\mathrm{Zn}$. Finally, these findings will help motivate our farmer to adopt seed priming technique to apply micronutrients like $\mathrm{Fe}$ and $\mathrm{Zn}$ in more efficient and effective way.

\section{Authors' contributions}

Conceived and designed the experiments: TA Khan \& ZI Ahmed, Performed the Experiments: TA Khan, MN Malik, M Irfan \& W Ahmad, Analyzed the Data: TA Khan \& S Syed, Contributed reagents/ materials/ analysis tools: A Baloch, A Latif, ZA Rahujo \& SM Hussain, Wrote the paper: TA Khan.

\section{References}

1. Food and Agricultural Organization of the United Nations (2009). FAOSTAT Statistical Data Base.

2. Food and Agricultural Organization of the United Nations (2013). FAOSTAT Statistical Data Base.

3. Khan N, Ullah F \& Imtiaz Uddin $M$ (2009). Agronomic characters of groundnut (Arachis hypogaea L.) genotypes as affected by nitrogen and phosphorus fertilization under rainfed condition. Electronic J Environ Agri and Food Chem 8(1): 61-68. 
4. Amjad M (2014). Status of oilseed crops of Pakistan. Plant Sci Div Pakistan Agric Res Council, Islamabad.

5. Government of Pakistan (2012). Crops area and production (by districts) 201112. Agriculture and Livestock, Ministry of Food, Islamabad 116-117.

6. Nawab K, Ullah A, Arif M, Shah P, Rab A, Khan MA, Khan MA \& Khalid K (2011). Effect of FYM, potassium and zinc on phenology and grain yield of wheat in rainfed cropping systems. Pak $J$ Bot 43(5): 2391-2396.

7. Marwat KB, Arif M \& Khan MA (2007). Effect of tillage and $\mathrm{Zn}$ application methods on weeds and yield of maize. Pak J Bot 39(5): 1583-1591.

8. Imtiaz M, Rashid A, Khan P, Memon MY \& Aslam M (2010). The role of micronutrients in crop production and human health. Pak J Bot 42(4): 25652578.

9. Malakouti MJ (2008). The effect of micronutrients in ensuring efficient use of macronutrients. Tur J Agric For 32: 215220.

10. Arif M, Jan MT, Marwat KB \& Khan MA (2008). Seed priming improves emergence and yield of soybean. Pak J Bot 40(3): 1169-1177.

11. Ali A, Khan MA, Saleem A, Marwat KB, Jan AU, Jan D \& Sattar S (2016). Performance and economics of growing maize under organic and inorganic fertilization and weed management. Pak $J$ Bot 48(1): 311-318.

12. Mengel K, Kirkby EA, Kosegarten H \& Appel T (2001). Principles of Plant Nutrition. Kluwer Academic Publishers, Dordrecht (Netherlands).

13. Singh MV (2007). Efficiency of seed treatment for ameliorating zinc deficiency in crops. In: Zinc Crops 2007, Improving Crop Production and Human Health, 24-26 May, 2007, Istanbul (Turkey).
14. Kobayashi T, Itai RN, Aung MS, Senoura T, Nakanishi H \& Nishizawa NK (2012). The rice transcription factor IDEF1 directly binds to iron and other divalent metals for sensing cellular iron status. Plant J 69: 81-91.

15. Greenshields DL, Liu G \& Wei $Y$ (2007). Roles of iron in plant defence and fungal virulence. Plant Signal Behav 2(4): 300-302.

16. Graziano M \& Lamattina L (2005). Nitric oxide and iron in Plants: an emerging and converging story. Trends Plant Sci 10(1): 4-8.

17. Farooq M, Basra SMA, Wahid A, Khaliq A \& Kobayashi N (2009). Rice seed invigoration. In: Lichtfouse E. editor. Sustainable Agriculture Reviews Springer (Netherlands) pp. 137-175.

18. Deering, RH \& Young TP (2006). Germination speeds of exotic annual and native perennial grasses in California and the potential benefits of seed priming for grassland restoration. Proc California Native Grasslands Assoc 16: 14-17.

19. Ali S, Arif M, Gul R, Khan A, Shah SS \& Ali I (2007). Improving maize seed emergence and early seedling growth through water soaking. Sci Khyber 19: 173-177.

20. Arif M, Ali S, Shah A, Javed N \& Rashid A (2005). Seed priming maize for improving emergence and seedling growth. Sarhad J Agric 21: 539-543.

21. Diniz KA, Silva PA, Oliveira JA \& Evangelista JRE (2009). Sweet pepper seed responses to inoculation with microorganisms and coating with micronutrients, amino acids and plant growth regulators. Sci Agric 66: 293297.

22. Singh MV (2003). Micronutrient seed treatment to nourish the crops at the critical stages of growth. Tech Bull IISS, Bhopal pp. 1-93. 
23. Godfery WN, Onyango JC \& Beck E (2004). Sorghum and salinity: II. Gas exchange and chlorophyll fluorescence of sorghum under salt stress. Crop Sci 44: 806-811.

24. Mirshekari B (2012). Seed priming with iron and boron enhances germination and yield of dill (Anethum graveolens). Turk J Agric For 36:27-33.

25. Ali AG \& Seyyed ANN (2010). Effects of iron and nitrogen fertilizers on yield and yield components of peanut (Arachis hypogaea L.) in Astaneh Ashrafiyeh, Iran. American-Eurasian J Agric and Envir Sci 9(3): 256-262.
26. Mirshekari B, Rahmani HA \& Roudsari AM (2010). Effect of seed inoculation with Azospirillum strains and coating with microelements on seed yield and essence of cumin (Cuminum cyminum L.). Iran J Medic Aromatic Plant 25: 470-481.

27. Ajouri A, Asgedom $\mathrm{H} \&$ Becker $\mathrm{M}$ (2004). Seed priming enhances germination and seedling growth of barley under conditions of $\mathrm{P}$ and $\mathrm{Zn}$ deficiency. J Plant Nut and Soil Sci 167:630-636. 